\title{
EGFR NP_005219.2:p.S752_V769del
}

National Cancer Institute

\section{Source}

National Cancer Institute. EGFR NP 005219.2:p.S752 V769del. NCI Thesaurus. Code C98580.

A deletion of 18 amino acids from the epidermal growth factor receptor protein from the serine at position 752 through the valine at position 769 . 